\title{
CIRCULAR ECONOMY AS AN INSTRUMENT OF NATURE CONSERVATION
}

\author{
Lidija Amidžić, \\ Dragiša Veličković, \\ Maja Vujčić Trkulja
}

Singidunum University, Belgrade, Serbia

\begin{abstract}
:
The exponential growth of human population results in the increased demand of natural resources, which leads to the accelerated degradation of natural ecosystems causing the unstoppable destabilization of the biosphere. Given the fact that the future of humankind is directly correlated with the level and quality of ecosystem services (ES), the increasing exploitation of natural resources is often followed by the enhanced struggle for its preservation. According to the report of the Tenth Meeting of the States Parties to the Biodiversity Convention held in Nagoya in 2010, the goal was to protect $17 \%$ of land and $10 \%$ of marine ecosystems by 2020 . Also, according to the study of the Economics of Ecosystem and Biodiversity (TEEB, 2010), the establishment of the protected areas network covering around $15 \%$ of the land and $30 \%$ of marine ecosystems would cost $\$ 45$ billion. On the other hand, global experts estimate that at the same time these areas would provide ES worth more than \$4.4 billion, suggesting that the investment in nature protection is cost-effective.
\end{abstract}

\section{Keywords:}

nature conservation, ecosystem services, biodiversity, circular economy, cost-effective.

\section{INTRODUCTION}

The need for nature conservation was discussed long before the development of modern science. Thus, even the ancient philosopher Plato (423-347 BC) advocated the conservation of forests, saying that extensive deforestation led to erosion of land and drying up of many springs. Owing to the initiative of Captain Molnar, Slavonia's military commander, the Austro-Hungarian court in 1874 protected the Obedska Bara as an imperial hunting ground. During the time of the Kingdom of Yugoslavia, the Obedska Bara was granted the status of the royal hunting ground of the Karadjordjević dynasty, while today it is a special nature reserve (Vujić, 2007).

In 1832, by a decree of the American president Andrew Jackson, the Hot Springs area in Arkansas was put under protection. The next major protected area in this part of the world was the Yosemite Valley located in the western part of the Sierra Nevada mountain range in California. Naturalist John Muir strongly advocated protection and promotion of the Yosemite Valley. Muir believed that contact with nature was essential for the development of human character and virtues. $\mathrm{He}$ founded the Sierra Club, the first non-governmental organization in the world to advocate for nature conservation (Vujić, 2007).

The US Congress proclaimed the world's first national park in 1872. It was the Yellowstone National Park that extends to Wyoming, Montana, and Idaho. The park was put under the federal authorities as "a public area for people enjoyment". Later, in 1916, the U.S. Congress also formed a The National Park Service with a director whose duty was to "preserve nature, all-natural and historical objects in the area, and to enable future generations to visit this place." (Vujić, 2007). 
In the course of the 19th and the 20th until the present around 238563 natural entities or objects established the status of protected areas of different categories: Ia Strict Nature Reserve (Category Ia), Ib Wilderness Area (Category Ib), National Park (Category II), Natural Monument or Feature (Category II), Habitat / Species Management Area (Category IV), Protected Landscape / Seascape (Category V) and Protected Area with Sustainable Use of Natural Resources (Category VI) (Dudley, 2008). These areas cover over $20.000 .000 \mathrm{~km} 2$, or around $14.9 \%$ of the world's mainland and about $6.000 .000 \mathrm{~km} 2$, or around $7.3 \%$ of the global ocean (Belle et al., 2018).

The biological, cultural and technological development has led to exponential growth and the main challenge of modern age society relates to facing the pressure from expanding populations. According to the United Nations report, around 7.7 billion people live on Earth and it is estimated that by 2030 this number will increase up to 8.5 billion, and by 2050 up to 9.7 billion (United Nations, 2018). Such an accelerated population growth entails the consumption of natural resources, increased urbanization, the more intensive environmental pollution, degradation of the natural habitat, erosion of biodiversity and the accelerated climate change (Dudley et al., 2010).For example, as a result of human action, about $54-57 \%$ of wetlands have been destroyed on Earth since 1990 (Davidson, 2014), and around 50\% of tropical rainforests have been cut down since the middle of the last century (Wilson, 2003; Nielsen, 2006). Also, these actions have contributed to the depletion of biodiversity, it was evidenced that 799 species known to science have disappeared since the 19th century (IUCN, 2013) and that $27 \%$ of the total estimated number of wild species is today close to extinction (Baillie et al., 2004; IUCN, 2019).

Increased commitment to protection and promotion follows the increasing level of natural degradation. To understand the principles of nature conservation, not only from the cultural, ethical or moral perspective, it is important to perceive nature through the prism of the ecosystem services it provides to the human population.

\section{ECONOMY BASED ASSESSMENT OF ECOSYSTEM SERVICES: A BRIEF OVERVIEW}

The economy based assessment of nature and its services emerged as a reaction to the decision-makers' shortterm concept of economic stability, where the attention was much more given to the "economic stability from a social aspect" than the conservation and sustainable use of natural resources. It is not enough to observe the economic growth and development only because they can be realized in different ways and at the cost of degrading nature and destroying its potential. Recycling can mitigate some negative effects of industrial development such as the irrational exploitation of natural assets. Recycling, as a part of a circular economy model, can replace a linear model (model of disrupt balance) of economy. A linear model of the highest production with uncontrolled use of natural resources involves the biggest amount of waste produced after. This model is irrational and unsustainable from the environmental and economic aspect.The implementation of a linear economy model in Serbia resulted in forming over 3,500 wild landfills and only 8 sanitary regional landfills. Due to that, only $5-7 \%$ of waste is recycled, while material worth $€ 50$ million is annually disposed in 150 non-sanitary landfills (Mitrović et al., 2017).

On the other hand, a circular economy implies a longterm economy principle of production that strives for the quality product and the return of waste materials to the production process using the product-waste-product model. Relying on this concept, the resources are used efficiently, production costs are reduced and the environment is preserved. The concept is essentially simple because it simulates the processes that take place in nature: the waste of one branch of industry is useful material for another. Therefore, a circular economy model supports the realization of the Sustainable Development Goals. Shifting from a linear to a circular economy model cannot be accomplished without initial costs and long-term investments, but the results are more than positive. The implementation of the new model is already providing good results. In the last nine years, over 70 companies in Serbia, with around 40,000 employees, have participated in projects involving a cleaner production process and chemical leasing. The average savings per company (excluding the project with Electric power of Serbia - EPS) are around $€ 100,000$ per year with: an average reduction in water consumption of 50,000 $\mathrm{m} 3$ / year, an average reduction in electricity consumption of $500 \mathrm{MWh} /$ year and an average reduction in $\mathrm{CO} 2$ emissions of 500t / year. Having realized all the advantages of a circular economy, the European Commission adopted a new legal framework for its implementation to strengthen the economy and ensure sustainable economic growth at the end of 2015 (Mitrović et al., 2017).

However, there are some limitations regarding the application of a circular economy model. The concept of sustainable development needs to be observed in a broader context with the focus on social well-being. For example, a condition in which resources are used in a way that enables the preservation of social production capabilities can be considered sustainable. Also, some resources are, by their very existence, essential for the physical and mental well-being of the human population, i.e. production of oxygen, but there are also numerous other benefits the value of which is almost impossible to determine accurately. Ecosystem services are examples of such benefits. They represent all the positive outputs that human population receives from natural resources and ecosystem processes. 
Ecosystem services are defined as human-based benefits of nature and ecosystem broadly distinguished as provisioning, regulating, supporting and cultural services (Millennium Ecosystem Assessment, 2005). Ideas on the ecosystem services and their evaluation were introduced by the American philologist George Perkins Marsh, who pointed out the negative effects of irrational exploitation of natural resources (Marsh, 1864). Unfortunately, Marsh's warnings were short-ranged, so the question of nature and ecosystem conservation to meet basic human needs remains a major concern. The idea of natural capital began in the middle of XX century (Osborn, 1948; Leopold, 1949), and some authors (Ehrlich \& Ehrlich, 1981) drew attention to the issue of ecosystem destruction upon which the existence of the human population depended. In 1970, the term "environmental services" was used in the Study of Critical Environmental Problems, which was conducted on the campus of Williams College, Massachusetts (SCEP, 1970). Ten years later, the term "environmental services" was replaced by another term still used today - "ecosystem services." All ecosystem services that human population receives from natural ecosystems fall into five basic categories:

1. Services supply - food of vegetable and animal origin, energy from fossil fuels, biomass and wood, raw materials for food, wood, chemical, pharmaceutical, textile and other industries, genetic resources, etc.

2. Services control - decomposition and circulation of matter, energy flow, the optimum ratio of gases in the atmosphere and mitigation of greenhouse effects, mitigation of climate extremes, purification of water and air, mitigation of flood waves, regulation of predators, parasites, and pathogens, etc.

3. Supporting services - primary production, land creation, land fertility and stability increase, nitrogen fixation, pollination, seed dispersal, the improvement in habitat conditions, etc.

4. Cultural services - motifs and inspiration for painting, literature, music, film, folklore, architecture, national symbols and religion, science and education development, the development of recreational activities, ecological, health and sports tourism development, etc.

5. Sports and recreation services - the optimal psychophysical condition of people, development of sports and recreational activities, ecological, health and sports tourism, etc.

In the last couple of decades, there is a strong body of evidence on the economic benefits of ecosystem services. Here are some examples listed below:

- The results of a feasibility study for the Yangtze River area showed that hydropower plants can maximize their productivity by preserving the forests that provide the optimum water flow. The assessment of hydropower forests conservation pointed out to a 2.2 higher profit compared to the profit realized by exploiting the timber of the same area (Guo et al., 2000).

- The Mississippi River example on ecosystem services of natural vegetation regarding the water regime of rivers revealed that the destruction of natural vegetation and wetlands on the banks of the river has significantly reduced its capacity to receive excess water, which resulted in frequent flooding. The damage recorded after the flood in 1993 was estimated at 12 billion dollars for the local population (Bhowmik et al., 1994).

- A case study involving aqueducts and canals and their potential role in improving the quality of drinking water transported from the Catskill Mountains to New York showed that the optimal solution for drinking water treatment could include the biological treatment involving natural vegetation. The amount of investment was estimated at 1-1.5 billion dollars. On the other hand, it was estimated that investment in artificial water treatment plants would cost around 6-8 billion dollars (Chichilnisky \& Heal, 1998).

- The example of the process of nitrogen fixation, bacteria of the genus Rhizobium and Bradyrhizobium attache about $175 \times 106$ tons of atmospheric nitrogen annually, which becomes available to plants. This is much more than the annual production of nitrogen fertilizers in the world, which amounts to around 40x106 tons. From the aspect of ecosystem services and economic benefit involving the process of nitrogen fixation, there is an interesting example where, a transformation of atmospheric nitrogen into a form available to plants in the USA provides an annual benefit up to 33 billion dollars (Alonso et al., 2001).

- Plants pollinated by wild pollinators (insects, birds, mammals) make up one third of human supplies. Indigenous pollinators annually provide the benefit of 40 billion dollars to agriculture through a plant product (Kibert, 1999), and at a global level, the economic value of pollination services is estimated at 217 billion dollars annually (Gallaiand Sales, 2009). However, there are fewer pollinators found on the crop due to the destruction of their natural habitats, excessive pollution and the application of pesticides and insecticides. For example, the use of pesticides on cotton crops in the USA reduces annual income by 400 million dollars (Kibert, 1999). 
NATURE CONSERVATION: THE COST BENEFITS AND INVESTMENTS

Given the fact that our world is facing critical environmental and social challenges such as extreme environmental pollution, climate change, and food and water security, protected areas can play a key role in the conservation of biodiversity and ecosystem services that in return could help us deal with these challenges. With regard to the above mentioned, at the Tenth Session of the Convention on Biodiversity Signatories, The Aichi Biodiversity Targets were set out, calling for, among other things, the relief of as much pressure on natural ecosystems as possible by 2020 , the termination of species extinction and the protection of at least $17 \%$ of terrestrial and $10 \%$ of marine ecosystems (CBD, 2010). According to the Study of Ecosystems and Biodiversity (TEEB, 2010), establishing a network of protected areas that would cover $15 \%$ of terrestrial and $30 \%$ of marine ecosystems would cost around 45 billion dollars. However, these areas would at the same time provide ecosystem services worth over 440 billion dollars, which is a higher amount of money than the one invested in their protection. The project of smart investment for America's health, economy, and environment recognize the investment in protected urban areas as powerful tools to addresses many challenges that cities are facing today. One of the case studies involving one of the largest urban parks in the US, Shelby Farms Park in Memphis, resulted in doubling the park's economic impact to more than $5 \%$ increase in propriety values within 150 meters radius and around 67 million dollars in property value-added (Georgia Tech Civil and Environmental Engineering department, 2017a). In addition to that, Reenvisioning Nashville's Natural Assets was much more than a short-term investment. Cumberland and Riverfront Parks were intended to remediate brownfields, preserve floodplains, and revitalize downtown Nashville's cultural and natural resources. The parks were built at a combined cost of $\$ 61.5$ million, and have helped generate $\$ 1$ billion in new investment within just two blocks of their boundaries (Georgia Tech Civil and Environmental Engineering department, 2017b).

Natural ecosystems are very diverse in organization and composition, interactions between species and the relationship with physical environment,; therefore, the capacity, quality, and sustainability of service provided can differ from one ecosystem to another. The economic value of global ecosystem services estimated on an annual level is between 16 and 54 billion dollars, with an average of 33 billion dollars (Costanza et al., 1997). However, many ecologists believe ecosystem services and global biodiversity are of incalculable value because nature is an irreplaceable resource of life and survival (Salles, 2011).
Nevertheless, the cost of investing in nature conservation is generally very low, and the financial resources intended for this purpose are often considered as an unnecessary expense by the decision-makers. The protection and revitalization of natural ecosystems is a process that provides sustainable use of natural assets and long-term investment that has proved to be cost-effective.

\section{CONCLUSION}

The benefits of natural ecosystems are recognized as the important nature conservation initiator for as many protected areas as possible both on a local and global level. In this sense, the circular economy or the green economy represents a new approach to nature protection that integrates economics and sustainable nature conservation the values of which can be understood through ecosystem services. The economy based assessment of natural assets and its ecological services lies in the fact that decision-makers pay much more attention to the cost-effective outputs and economic stability and much less to the sustainable use and conservation of natural resources. Therefore, maintaining a balance between natural capital and the growth of human-created capital is essential. Increasing social benefits is desirable only if it is sustainable in the long run, and so long as this increase does not come at the expense of natural assets and human well-being.

\section{REFERENCES}

1. Alonso, A., Dallmeier, F., Granek, E., Raven, P.(2001). Biodiversity. Connecting with the tapestry of life. Smithsonian Institution, Monitoring and assessment of Biodiversity Program and President's Committee of Advisors on Science and Technology. Washington.

2. Baillie, JEM., Hilton-Taylor, C., Stuart., SN (eds.) (2004). IUCN Red List of Threatened Species, A Global Species Assessment. IUCN. Gland Switzerland, Cambridge UK.

3. Belle, E., Kingston, N., Burgess, N. (UNEP-WCMC); Sandwith, S., Ali, N. (IUCN); MacKinnon, K. (IUCN WCPA) (eds.) (2018). Protected Planet Report 2018. Tracking progress towards global targets for protected areas. United Nations Environment Programme ISBN No: 978-92-807-3721-9

4. Bhowmik, N. G., Buck, A. G., Changnon, S. A., Dalton, R. H., Durgunoglu, A., Demissie, M., Juhl, A. R., Knapp, H. V., Kunkel, K. E., McConkey, S. A., Scott, R. W., Singh, K. P., Soong, T. D., Sparks, R. E., Visocky, A. P., Vonnahme, D. R., Wendland, W. M. (1994). The 1993 flood on the Mississippi River in Illinois. Illinois State Water Survey, Champaign. Miscellaneous Publication 151. 149 pp.

5. Chichilnisky, G. \&Heal, G. (1998). Economic returns from the biosphere. Nature. Vol. 391: 629-630. 
6. Costanza, R., d'Arge, R., de Groot, R., Farberk, S., Grasso, M., Hannon, B., Limburg, K., Naeem, Sh., O’Neill, R., Paruelo, J., Raskin, R., Sutton, P., Vaden Belt, M. (1997). The value of the world's ecosystem services and natural capital. Nature, 387(6630): 253-260.

7. Davidson, N. (2014). How much wetland has the world lost? Long-term and recent trends in global wetland area. Marine and Freshwater Research.http://dx.doi. org/10.1071/MF14173

8. Dudley N. (ed.) (2008).Guidelines for Appling Protected Areas Management Categories. IUCN, Switzerland. ISBN 978-2-8317-1086-0

9. Dudley, N., Stolton, S., Belokurov, A. et al (eds.) (2010). Natural solutions: protected areas helping people cope with climate change. IUCN/World Bank/WWF. Gland.

10. Ehrlich, P. R.\&Ehrlich, A. H. (1981). Extinction: The cause and consequences of the disappearance of species. Random House. New York, 72-98.

11. Gallai, N. \& Sales, J. (2009). Economic valuation of the vulnerability of world agriculture confronted with pollinator decline. Ecological Economics, 68: 810-821.

12. Georgia Tech Civil and Environmental Engineering department, (2017a). Shelby Farms Park, Memphis, TN.

13. Georgia Tech Civil and Environmental Engineering department, (2017b). Cumberland and Riverfront Parks, Nashville, TN.

14. Guo, Z. W., Xio, X. M., Li, D. M. (2000). An assessment of ecosystem services: Water flow regulation and hydroelectric power production. Ecological Applications 10: 925-936.

15. IUCN (2013). The IUCN Red List of Threatened Species. https://www.iucnredlist.org/

16. IUCN (2019).The IUCN Red List of Threatened Species. https://www.iucnredlist.org/

17. Kibert, Ch. (Ed.) (1999). Reshaping the Built Environment: Ecology, Ethics and Economics. Island Press. Washington: 362.

18. Leopold, A. (1949). A Sand County Almanac and Sketches from Here and There. Oxford University Press. New York.

19. Marsh, P.G. (1864). Man and nature: Physical geography as modified by human action. Charles Scribner's Sons. New York. 472.

20. Mitrović, S., Radosavljević, I., Veselinov, M. (2017).Cirkularna ekonomija kao šansa za razvoj Srbije. Organization for Security and Co-operation in Europe.https://www.osce. org/en/serbia/292311?download=true

21. Nielsen, R. (2006). Seven Trends Shaping the Future of Our Planet: 1-365. The Little Green Handboo.:Picador, New York. ISBN: 9780312425814

22. Osborn, F. (1948). Our Plundered Planet. Little, Brown and Company. Boston.

23. Salles, J.M. (2011). Valuing biodiversity and ecosystem services: Why put economic values on Nature?" ComptesRendusBiologies, 334(5-6): 469-82.
24. SCEP, (1970). The Williamstown Study of Critical Environmental Problems, Bulletin of the Atomic Scientists, 26:8, 24-30, DOI: 10.1080/00963402.1970.11457855

25. TEEB, (2010). The Economics of Ecosystems and Biodiversity: Mainstreaming the Economics of Nature: $A$ synthesis of the approach, conclusions and recommendations of TEEB.

26. Vujić, A. (2007). Osnove konzervacione biologije II. Departmant za biologiju i ekologiju, Prirodno-matematički fakultet Univerziteta u Novom Sadu. ISBN 978-86-7031-120-6.

27. United Nations, Department of Economic and Social Affairs (2018). Population Division. World Urbanization Prospects. ISBN 978-92-1-148318-5

28. Wilson, E. O. (2003). The Future of Life: 1-256. Vintage. ISBN 0-679-76811-4 